\title{
Introduction à la section 3
}

Michel Petit

\section{(2) OpenEdition}

\section{Journals}

Édition électronique

URL : http://journals.openedition.org/asp/3014

DOI : 10.4000/asp.3014

ISSN : 2108-6354

\section{Éditeur}

Groupe d'étude et de recherche en anglais de spécialité

\section{Édition imprimée}

Date de publication : 1 décembre 1997

ISSN : 1246-8185

\section{Référence électronique}

Michel Petit, «Introduction à la section 3 », ASp [En ligne], 15-18| 1997, mis en ligne le 25 mai 2012, consulté le 21 septembre 2020. URL : http://journals.openedition.org/asp/3014 ; DOI : https://doi.org/ 10.4000/asp.3014

Ce document a été généré automatiquement le 21 septembre 2020

Tous droits réservés 


\title{
Introduction à la section 3
}

\author{
Michel Petit
}

1 Les textes de cette section 3 sont fondés sur les communications présentées au Colloque «Quelle stylistique pour l'étude du discours scientifique en anglais? » organisé les 13 et 14 octobre 1995 à l'Université de Provence à Aix-en-Provence dans le cadre de l'Institut de Recherche du Monde Anglophone avec le soutien du Conseil Scientifique de l'Université de Provence.

2 Textes publiés sous la responsabilité éditoriale de Michel Petit

3 Responsable du colloque : Michel Petit

4 Comité scientifique du colloque : Gilles Mathis, Michel Perrin, Michel Petit et Serge Ricard 